\title{
Notes on the Distribution of the Central American Collared Geckolet, Sphaerodactylus glaucus (Squamata: Sphaerodactylidae), in Quintana Roo, Mexico
}

\author{
Oscar Cid-Mora ${ }^{1}$ and Victor Vásquez-Cruz ${ }^{2}$ \\ ${ }^{1}$ Grupo Xcaret, Carretera Chetumal-Puerto Juárez Km 282. CP. 77710 Playa del Carmen, Quintana Roo, México \\ 2PIMVS Herpetario Palancoatl, Avenida 19 número 5525, Colonia Nueva Esperanza, Córdoba, Veracruz, México (victorbiolvc@gmail.com)
}

$\mathrm{T}$ he Central American Collared Geckolet, Sphaerodactylus glaucus (Squamata: Sphaerodactylidae), ranges from southern Mexico into Guatemala and Honduras. In Mexico, it occurs in the states of Veracruz, Oaxaca, Tabasco, Chiapas, Campeche, Yucatán, and Quintana Roo (Lee 2000; GarcíaGrajales et al. 2014). This species occurs in a variety of natural habitats, including tropical wet forest, tropical moist forest, tropical dry forest, tropical very dry forest, and subtropical moist forest, as well as anthropogenically modified habitats such as coffee and banana plantations and within houses (Wilson and Johnson 2010; Vásquez-Cruz et al. 2018). Sphaerodactylus glaucus is a small gecko (SVL to $29 \mathrm{~mm}$; Köhler 2008) that is easily distinguished from S. argus by its coloration and pattern and from S. millepunctatus by its smooth dorsal scales.
At about $1100 \mathrm{~h}$ on 17 August 2017, OCM found a Sphaerodactylus glaucus (SVL $=13 \mathrm{~mm}$; Fig. $1 \mathrm{~A}$ ) in the Ecoarceological Park Xcaret $\left(20^{\circ} 34^{\prime} 50.72^{\prime \prime N}\right.$, -8707'10.32"W; WGS 84; elev. $11 \mathrm{~m}$ ), Municipality of Solidaridad, Quintana Roo, Mexico. The individual was photographed and released. We deposited a photographic voucher in the herpetological collection of the Natural History Museum of Los Angeles (LACM PC 2472).

At about 1800 h on 10 March 2019, OCM found a Sphaerodactylus glaucus (Fig. 1B) on a construction pillar in Park Xel-Há $\left(20^{\circ} 19^{\prime} 09.69^{\prime \prime N},-87^{\circ} 21^{\prime} 28.12^{\prime \prime W}\right.$; WGS 84; elev. 5 m), Municipality of Cozumel, Quintana Roo, Mexico. The gecko was not captured, but we deposited a photographic voucher in the herpetological collection of the Natural History Museum of Los Angeles (LACM PC 2473). Subsequently, at
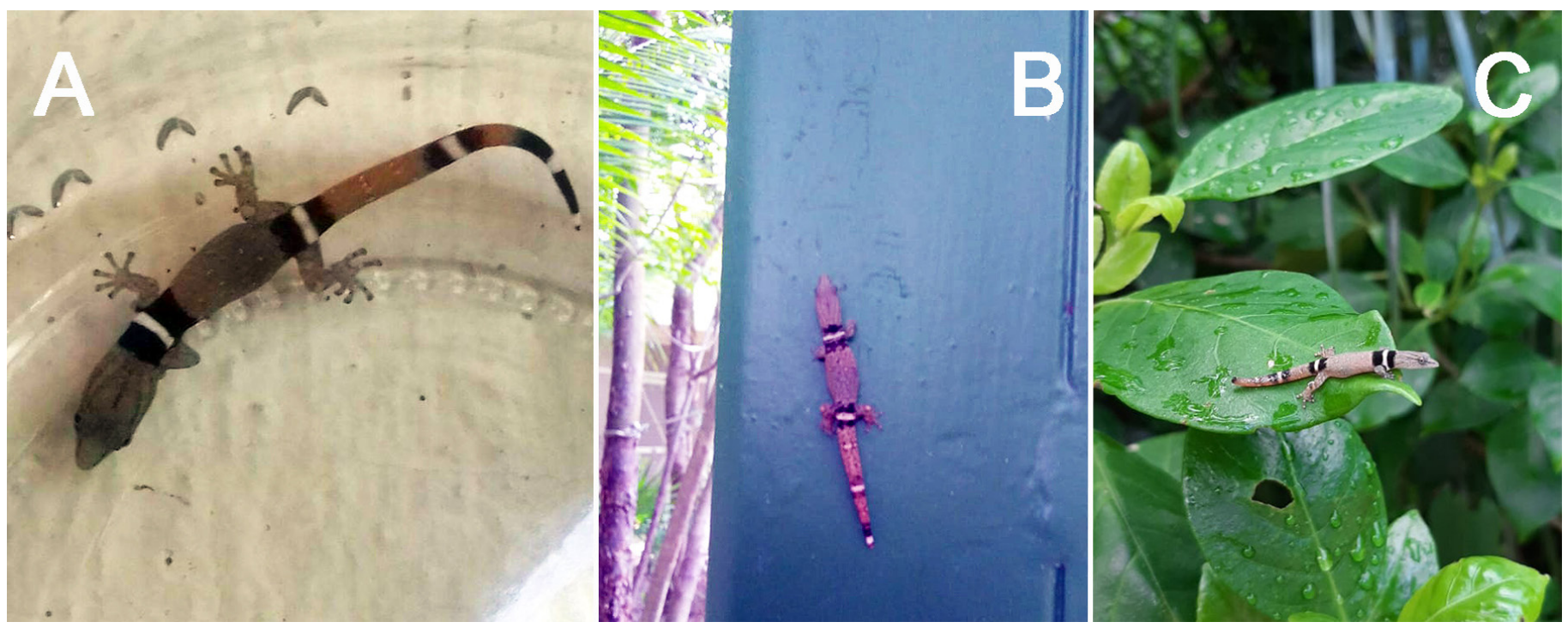

Fig. 1. Central American Collared Geckolets (Sphaerodactylus glaucus) from the Ecoarceological Park Xcaret, Municipality of Solidaridad, Quintana Roo, Mexico (A) and from Park Xel-Há, Municipality of Cozumel, Quintana Roo, Mexico (B \& C). Photographs by Oscar Cid-Mora. 


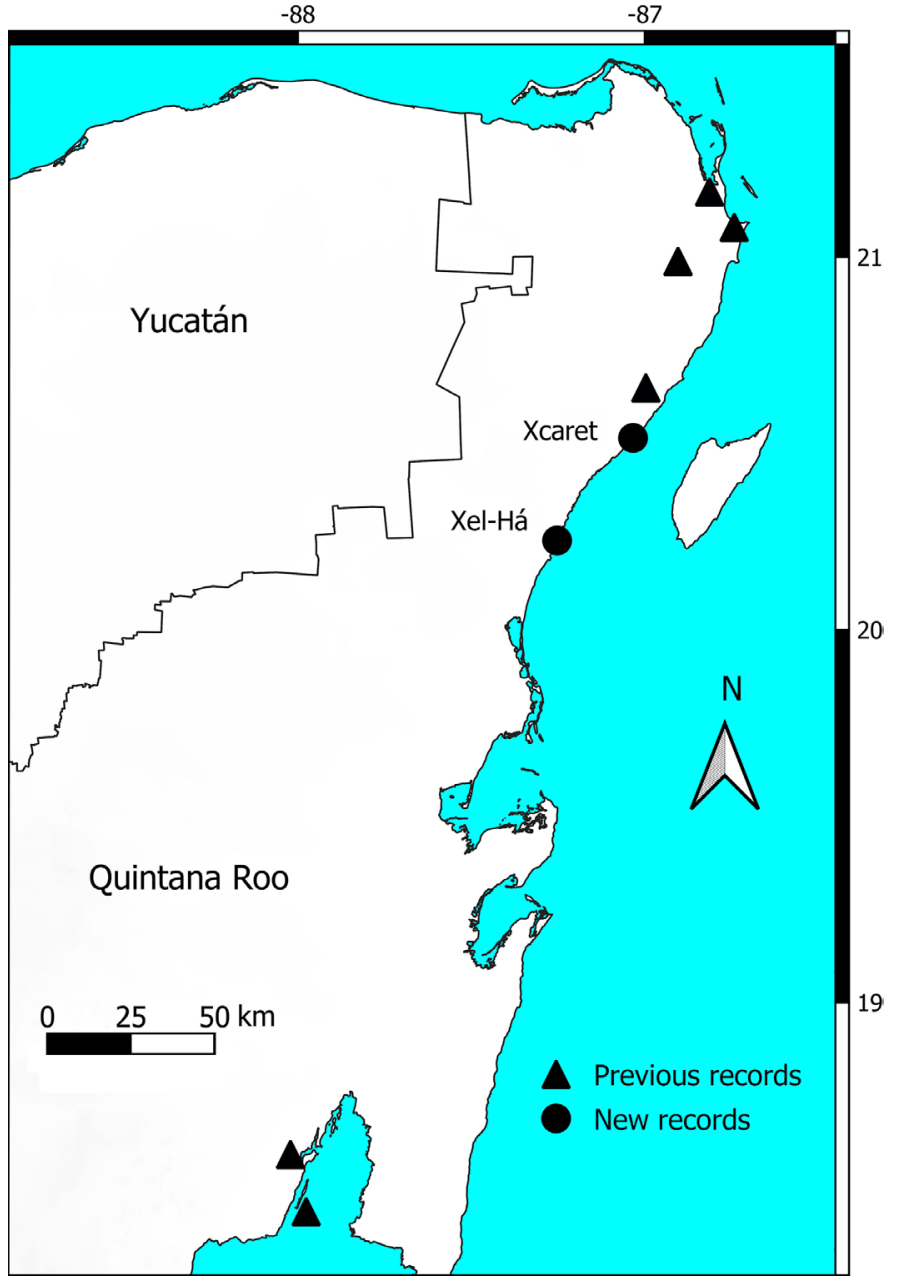

Fig. 2. Locality records for the Central American Collared Geckolet (Sphaerodactylus glaucus) in Quintana Roo, Mexico.

about 0800 h on 7 November 2019, OCM photographed an adult perched on an ornamental plant (Fig. 1C).

These observations represent a new municipal record for the Municipality of Cozumel and the second record in the
Municipality of Solidaridad, Quintana Roo (Fig. 2). They are 16 and $53 \mathrm{~km} \mathrm{SSW}$, respectively, of the closest previously documented record (10 km N of Playa del Carmen; Parmerlee and Powell 1980). The species had been reported previously in the municipalities of Othon P. Blanco, Isla Muejeres, Benito Juárez, and Solidaridad (Lee 1980, 2000; Parmerlee and Powell 1980; García-Grajáles et al. 2014). This species is listed as "Subject to Special Protection (Pr)" (NOM-059-2010; SEMARNAT 2010), so documenting its distribution and noting its potential tolerance to urbanization are important.

\section{Acknowledgements}

We thank Neftalí Camacho (LACM) for cataloguing the digital photographs.

\section{Literature Cited}

García-Grajáles, J., A. Buenrostro-Silva, and V. Mata-Silva. 2014. Range extension of the least gecko, Sphaerodactylus glaucus Cope, 1865 (Squamata: Sphaerodactylidae) in Oaxaca, Mexico. Check List 10(1): 205-206.

Köhler, G. 2008. Reptiles of Central America. Herpeton Verlag Elke Köhler, Offenbach, Germany.

Lee, J.C. 1980. An ecogeographic analysis of the herpetofauna of the Yucatán Peninsula. University of Kansas Museum of Natural History Miscellaneous Publication 67: 1-75.

Lee, J.C. 2000. A Field Guide to the Amphibians and Reptiles of the Maya World. The Lowlands of Mexico, Northern Guatemala, and Belize. Comstock Publishing Associates, Cornell University Press, Ithaca, New York.

Parmerlee, J. and R. Powell. 1980. Geographic distribution: Sphaerodactylus glaucus (dwarf gecko). Herpetological Review 11: 115-116.

SEMARNAT (Secretaría del Medio Ambiente y Recursos Naturales). 2010. Norma Oficial Mexicana NOM-059-ECOL-2010. Protección ambientalespecies nativas de México de flora y fauna silvestres. Categorías de Riesgo y especificaciones para su inclusión, exclusión o cambio-Lista de Especies en Riesgo. Diario Oficial de la Federación (Segunda sección: 30 de diciembre).

Vásquez-Cruz, V., A. Kelly-Hernández, A. Reynoso-Martínez, and A. FuentesMoreno. 2018. Geographic distribution: Sphaerodactylus glaucus. Herpetological Review 49: 717.

Wilson, L.D. and J.D. Johnson. 2010. Distributional patterns of the herpetofauna of Mesoamerica, a biodiversity hotspot, pp. 31-235. In: L.D. Wilson, J.H. Townsend, and J.D. Johnson (eds.), Conservation of Mesoamerican Amphibians and Reptiles. Eagle Mountain Publishing, LC, Eagle Mountain, Utah. 